\title{
Growth of Companies: Empirical Study of the Companies Listed in Developing Economies
}

\section{Pertumbuhan Perusahaan: Studi Empiris Perusahaan Yang Terdaftar di Negara Berkembang}

\author{
Tariq TawfeeqYousif Alabdullah ${ }^{1 *}$, Essia Ries Ahmed ${ }^{2}$, Sami Abushammala ${ }^{3}$ \\ ${ }^{1}$ Accounting Department, University of Basrah, Iraq, ${ }^{2}$ Economics, Management and Information Systems, University of \\ Nizwa, Oman, ${ }^{3}$ University Collage of Applied Scinces, , Palestine
}

OPEN ACCESS

ISSN 2548-3501 (online)

Edited by:

Eny Maryanti

Reviewed by:

Yasser Alrawi

${ }^{*}$ Correspondence:

Tariq TawfeegYousif Alabdullah

tariqtariq1984@gmail.com

Received: April 2020

Accepted: June 2020

Published: 31 Juli 2020

Citation:

Alabdullah TT, Ahmed ER and Abushammala S (2020) Growth of Companies: Empirical Study of the

Companies Listed in Developing

Economies.

Journal of accounting Science. 4:2

doi: 10.21070/jas.v4i2.677
The aim of this study is to investigate the impact of some control determinants on growth of companies as a reflection to an economic perspective. The methodology used in the current study is cross sectional for a sample of companies belonging to industrial and service sectors (non-financial sector) for the year of 2019 in developing economies. We find a positive link between a number of board members and companies' growth, while leadership position has insignificant link to companies' growth. This means that an important policy implication should be considered by policy makers and management in the companies to increase numbers of members in the board of directors which is worth towards enhancement of companies' growth. The value and originality of this study lies in its results that should be taken into account by several interested parties such as the management in the companies who engage in behavior that leads to maintaining strong control determinants, and also the financial analysts who manage studies on control determinants to enhance companies' growth and further the policymakers who design and implement plans of such determinants. Thus, the value of the present study is to have a good contribution added to the body of knowledge in the field of economics, finance and accounting through investigating the impact of control determinants on economic growth. Based on the best knowledge of the researchers, a few studies have investigated the link between control determinants and economic growth by measuring economic growth via market share as a proxy of economic growth in this area.

Keywords: Financial market, companies' growth, control determinants, industrial and service sectors, developing economies.

Tujuan dari penelitian ini adalah untuk mengetahui dampak beberapa faktor penentu pengendalian terhadap pertumbuhan perusahaan sebagai cerminan dari perspektif ekonomi. Metodologi yang digunakan dalam penelitian ini adalah cross sectional untuk sampel perusahaan yang tergabung dalam sektor industri dan jasa (sektor non keuangan) untuk tahun 2019 di negara berkembang. Kami menemukan hubungan positif antara jumlah anggota dewan dan pertumbuhan perusahaan, sementara posisi kepemimpinan memiliki hubungan yang tidak signifikan dengan pertumbuhan perusahaan. Artinya, implikasi 
kebijakan yang penting perlu diperhatikan oleh pengambil kebijakan dan manajemen di perusahaan untuk meningkatkan jumlah anggota direksi yang bermanfaat untuk peningkatan pertumbuhan perusahaan. Nilai dan orisinalitas penelitian ini terletak pada hasilhasilnya yang harus diperhitungkan oleh beberapa pihak yang berkepentingan seperti manajemen di perusahaan yang terlibat dalam perilaku yang mengarah pada mempertahankan determinan pengendalian yang kuat, dan juga analis keuangan yang mengelola studi tentang pengendalian. faktor penentu untuk meningkatkan pertumbuhan perusahaan dan selanjutnya pembuat kebijakan yang merancang dan mengimplementasikan rencana penentu tersebut. Dengan demikian, nilai dari penelitian ini adalah memiliki kontribusi yang baik untuk menambah pengetahuan di bidang ekonomi, keuangan dan akuntansi melalui investigasi dampak determinan pengendalian terhadap pertumbuhan ekonomi. Berdasarkan pengetahuan terbaik para peneliti, beberapa penelitian telah menyelidiki keterkaitan antara penentu pengendalian dan pertumbuhan ekonomi dengan mengukur pertumbuhan ekonomi melalui pangsa pasar sebagai proksi dari pertumbuhan ekonomi di daerah ini.

Keywords: Pasar finansial, pertumbuhan perusahaan, faktor penentu kontrol, sektor industri dan jasa, ekonomi berkembang. 


\section{INTRODUCTION}

The series of global crises continues, due to which the financial, economic, and even social crises continue, the last of which is the Coronavirus crisis Alabdullah et al. (2020) . As a result, in the last decades, it is notable that developed and developing economies have been focused on improving their economic growth and the economic situation in general. For instance, after Asian financial crisis in 1998 with other crises and failure in big companies such as WorldCom and Enron in USA and Europe, there was a notable mistrust on majority of companies around the world in different discipline that is mentioned by several previous studies such as Abushammala et al. (2015), Ahmed et al. (2019), Ahmed et al. (2020) , Alabdullah et al. (2018); Ahmed et al. (2014a), Ahmed et al. (2018c,a,b,d), Alfadhl and Alabdullah (2013), Alabdullah et al. (2014a), Ahmed et al. (2012), Ahmed and \&amp;zuqibeh (2013), Ahmed et al. (2013), Ahmed et al. (2014b) .Such failures and problems were reasons to shed the light on the operations and transactions in-house and staff included in companies that receive big amount of money of short-term debts without stockholders' knowledge. Such debts were hidden via several accounting and management methods with support of innovation systems. Investigations have been done because of these problems and collapse and one of the results of the investigations revealed that that reason behind these problems was the manipulation in accounting data. Thus, huge attention has been introduced to control determinants and mechanisms to ensure protection for the investors and other interested parties and (2019), Rahim et al. (2019), and (2019), Thottoli et al. (2019), Alabdullah (2018), Hashim et al. (2019a), Alabdullah (2017), Alabdullah (2016a), Alabdullah (2016e) Alabdullah (2016e) Alabdullah (2016c), Alabdullah (2016d), Alabdullah (2016b), Alabdullah and Ahmed (2018), Alabdullah et al. (2018), Hashim et al. (2019b) .Control determinants matter has become one of the most important topics in business and investment environment in both developed and developing countries. These determinants are considered as a vital instruments that positively could be used to control the companies and govern their accountability. Furthermore, it is considered to be useful for shareholders and all interested parties of the stakeholders Alabdullah (2016a). These determinants are ancient and their roots go back to several hundreds of years (Alabdullah et al. (2014a,b,c) . Value creation and economic growth are very important for innovation enhancement, where several countries put this importance in their consideration as both India and China are focusing on the innovation that they got a title of a centre of innovation for the last decade Omar (2019) . In spite of obligation by many countries for economic reforms in the developing economies, the problem is still existing and the weakness in economic performance is below the acceptable performance level and (2019). This has led to the necessity to have response to calls for new researches to be done by scholars and academics in the area of the economic growth and control determinants' mechanisms. Therefore, our study investigates the impact of control determinants on economic growth in manufacturing industrial companies due to their positive impact on the economic growth in developing economies. Increases in board size and the separate leadership position are likely to have consequences for economic growth. The main focus of this work is to investigate whether there is a positive link between economic growth and the size of directors, and secondarily, to investigate whether there is a positive link between the non-duality of the leadership and economic growth, noting that the two links could be interconnected.

For the practical implications, the advice of the present work is that the authorities should take the substantial proceedings to focus and give more attention to large board size in the companies in order to positively enhance its economic growth and then eventually to promote economic growth of the country in the long run.

Corporate governance system has got a remarkable attention that was really required by companies to have a notable performance Ali and Zarowin (1992), Alabdullah et al. (2016) . Based on the code on issued by ASE for companies listed in the financial market, the board size in a company should have a number of members that are not more than fifteen and not less than three. Previous studies in economics and management literature such as Pfeffer (1972) confirms that board size is a vital matter on firm profitability and economic growth in addition to the success, and it is considered as one of control determinants which control and reduces agency problems and plays a key role in economy of the countries Ali et al. (2017) , Yermack (1996) . Majority of the previous work admit that there is a positive link between large size of board and economics growth Fauzi and Locke (2012) confirming that this determinant leads to alleviating agency costs and enhancing economic growth.

Duality in the board of directors leads to effect negatively on transparency within the corporation. On the other hand, Baliga et al. (1996) show that the CEO-Chairman duality has a weak impact on profitability. However, to appoint manager to play duality role would lead to establish power by this a person and then might strongly impact on board ability for control. Therefore, duality minimize stockholders wealth and weaken organizational profitability.

Thus, we forecast a hypothesis regarding the link of board size and economic growth,.

H1: A positive link between larger board and economic growth.

On the other hand, we have the leadership position as an exogenous variable that revealed it has a positive impact on economic growth. Several studies as explained by Jensen and Meckling (1976) state that CEO duality in the board of directors means one person is making decision and this leads to increasing ineffective monitoring and supervision. That means that one person will be as a chairman and as general manager in the company who is making decisions. Several studies have tested this determinant in the literature review and they mentioned its importance in proving economic growth. For exam- 
ple DiPeitro and Anoruo (2012), Ahmed et al. (2020) . Empirical studies such as Yermack (1996) find that board size is matter and significant factor that affects the level of profitability and economic growth. Alabdullah et al. (2016) and Alabdullah et al. (2020) admit that separating the role of the chairman from the role of the CEO promotes and maximizes economic growth represented by market share (Based on previous studies, we predict this hypothesis:

H2: A positive link between non duality and economic growth.

\section{METHOD}

\section{Data and Measurement}

This work chose non-financial companies for one of developing economies represented by Jordan to deal with its nonfinancial firms and to analyze their data as cross sectional work based on the annual reports as a primary data collection for the year of 2019. The reason behind choosing this year is that the data could be found and was available online. The other reason is that once we choose this year, the finding of our study will reflect good indicators that can be taken into account by many interested parties in this country and also the other countries in the developing economies. This study excludes financial firms that belong to financial sector because this kind of companies has their own regulations that are different from the nonfinancial sector Alabdullah et al. (2014a). To serve the present study in achieving its purposes, we collected the data of the companies listed in ASE based on the annual reports for measuring all the variables of the current study.

The measurements of the variables selected in the present work represented by its independent and dependent variables are starting with the independent variables which are board of directors size (BSIZE ) that is measured by collecting the number of directors in the board of directors, and leadership position as a second dependent variable that is measured whether or not the chairman is the same person who is the CEO during the year, where it takes " 1 " if the CEO is also appointed as a chairman, and "0" otherwise Ali and Zarowin (1992). For the dependent variable which is the economic growth represented by market share (MS) is measured as net sales divided by the total sales of the industry. The current work also takes into its account the firm size as a control variable to be used in the current work and it is measured as Natural logarithmic of the firm's total assets.

\section{RESULT AND DISCUSSION}

\section{Variables analysis}

\section{Descriptive and Correlations analyses:}

This part explains the descriptive analysis of the current work variables regarding dependent the variables of the current work for the 65 industrial and serves companies listed ASE via uti- lizing descriptive analysis for the sample.

The results show that economic growth represented by market share (MR) revealed that the mean of this variable in the nonfinancial Jordanian firms is $47.9 \%$ with a st.v of 0.287 . Furthermore, minimum rate of economic growth that is measured by market share (MR) in the nonfinancial Jordanian firms is 8 $\%$ with maximum of $94 \%$. Also, the descriptive reveals that the range of board size (BSIZE) of the current work is about nine members (the mean is 8.89) with a St.dv of 3.359. For the leadership positions (CDUAL), the descriptive statistic showed that of the 65 firms of the sample of this work, $32 \%$ the chairman is CDUAL and non-duality is $68 \%$, the same person holding this position. Table 1 illustrates all details about the distribution of the variables.

\section{[Table 1 about here.]}

The table above reveals that skewness (SK) and kurtosis (KU) value of the sample shows it is normally distributed due to the standard value for both (SK) and (KU) are within the range of normality which is within \pm 3 for the KU and \pm 1.96 for standard of SK as this condition is demonstrated by Brooks (2014)

The correlation test between the two independent variables (BSIZE and CDUAL ) shows that they have negative relationship which is $(-0.718)$. This value reflects a good indicator about the multicollinearity problem. In that, there is no multicollinearity problem between the independent variables in the current work because the value is less than $80 \%$. To admit that the sample is free from this problem, the value of the VIF is not more than 10 as it is clear that BSIZE is 2.063 and CDUAL is 2.063 and both values are less than 10 . Table 2 shows the correlation between the independent variables.

[Table 2 about here.]

L. of sig. ${ }^{*} \mathrm{p}<.10,{ }^{* *} \mathrm{p}<.05$

In Table 3 , regression analysis was run and the outputs show a positive link between a board size and companies' growth represented by market share $(\mathrm{t}$-value $=2.502, \mathrm{P}<.00$, ).

This revealed that large board size is linked with higher companies' growth. This finding introduces a support to some of previous researches as what was done by Alabdullah et al. (2014a) . Therefore, this finding is consistent with $\mathrm{H} 1$, a positive link between larger board of directors' size and economic growth. As a result, hypothesis $\mathrm{H} 1$ is supported. In addition, the findings of the reveal that there is no link between leadership position (non-duality) and economic growth, which means that there is an insignificant relation between this determinant and economic growth (CDUAL; $\beta=-.804$ ). In our sample, although several firms in the non-financial sector in Amman resort to apply non-duality policy (where 67.7 percentage for the firms that have two separate persons holding $\mathrm{CEO}$ and chairman that is equal to 44 firms, while $21 \mathrm{firms}$ apply duality policy), there was an insignificant link between non duality and companies growth $(\mathrm{t}$-value $=-.804, \mathrm{P}<.1)$. 
Thus, this finding is not in line with $\mathrm{H} 2$ that says: there is a positive link between non duality and economic growth. Therefore hypothesis (H2) is not supported. Regression analysis is explained in Table 3

[Table 3 about here.]

L. of sig. ${ }^{*} \mathrm{p}<.10,{ }^{* *} \mathrm{p}<.05,{ }^{* *} \mathrm{p}<.01$

\section{IMPLICATIONS AND RECOMMENDATIONS}

The current work has empirical and theoretical implications. An empirical implication is mentioned by the current work regarding CG in Jordan. CG practice in Jordan has no effect on mechanism of CEO and chairman non duality in the companies belonging to industrial and service sectors (non-financial sector). From a literature perspective, a theoretical implication regarding economic and financial systems is likely focusing on elements that faced mismanagement and also slack cash balances. The recommendations for the future research lies in explaining several matters. First, the fact that CG systems in Jordan environment has to be faced with debate over several issues: There is no study done in such context to deal with CG and non-financial performance. Third, foreign ownership as an important control mechanism has not been sufficiently tested by scholars and academics except one study by Alabdullah (2018) . Fourth, managers' remuneration is a convincing issue to be taken into account by scholars specialised in CG.

\section{CONCLUSION}

The globalization and the fast development of technology in light of the manipulation have called for a critical need to

\section{REFERENCES}

Abushammala, S. N., Alabdullah, T. T. Y., and Ahmed, E. R. (2015). Causal Relationship between Market Growth and Economic Growth. Comparison Study. European Journal of Business and Management 7.

Ahmed, E. R., Alabdullah, T. T. Y., Amran, A., and \&amp;yahya, S. B. (2018a). Indebtedness Theory and Shariah Boards: A Theoretical Approach. Global Business and Management Research 10, 127-134.

Ahmed, E. R., Alabdullah, T. T. Y., Thottoli, M. M., and Maryanti, E. (2020). Does Corporate Governance Predict Firm Profitability? An Empirical Study in Oman. The International Journal of Accounting and Business Society 28, 127-143.

Ahmed, E. R., Alabdullah, T. Y., Islam, M. A., and Asmar, M. (2014a). Sukuk Legitimacy: A New Measurement Based on Content Analysis" 16th Malaysian Finance Association Conference in SasanaKijang Central Bank of Malaysia (Kuala Lumpur).

Ahmed, E. R. and \&amp;zuqibeh, A. (2013). The role of shariah supervisory board in the reviewing and supervision on takaful (islamic insurance). Insurance and Takaful Journal.

Ahmed, E. R., Amran, A., and Islam, M. A. (2018b). Sukuk Documentation and Legitimacy: The Role of Shariah Supervisory Board as a Moderator. International Academic Journal of Accounting and Financial Management 05, 22-40. doi: 10.9756/iajafm/v5i2/1810015.

Ahmed, E. R., Islam, A., and \&amp;yahya, S. (2014b). Comparative study of Zakat and taxation system for Muslims and Non-Muslims in Malaysia. Advances in Environmental Biology, 549-554. convert from traditional to modern methods in dealing with economic growth. Given that, there should be new studies to contribute to the field of economic development in order to recover and also overcome the sudden crises such as what has happened recently, the emergence of Coronavirus that have globally been considered as severe pandemic hitting the economic and social situations alike in all developed and developing economies. From the previous studies in the literature linking CG determinants and economic growth, it is clear that the results therein are inconsistent. There is a lack in the literature in Asia and the Middle East in testing the link between control determinants and the economic growth of nonfinancial companies. Therefore, the current work chose Jordan to investigate this link and its findings could be generalized to include the rest of the other countries in the Middle East, which have traits and benefits close to Jordan, including characteristics that cover economic, social, and even the competitive advantages that are similar to the work environment. The findings revealed that such countries including Jordan have to put more attention to the control mechanism because it was found to be insignificant although that majority of companies in non-financial sector has followed and applied this mechanism. Moreover, there should be more focus in caring for the formation of a board of directors by a large size of members, because such a structure has positive impact on economic growth for Jordanian companies.

\section{ACKNOWLEDGMENT}

The Authors wish to acknowledge Eny Maryanti From Universitas Muhammadiyah Sidoarjo Indonesia for her assistance in publishing this paper, her help is greatly appriciated
Ahmed, E. R., Islam, A., and Amran, A. B. (2019). Examining the legitimacy of Sukuk structure via Shariah pronouncements. Journal of Islamic Marketing 10, 1151-1166. doi: 10.1108/jima-03-2018-0050.

Ahmed, E. R., Islam, M. A., Alabdullah, T. T. Y., and bin Amran, A. (2018c). Proposed the pricing model as an alternative Islamic benchmark. Benchmarking: An International Journal 25, 2892-2912. doi: 10.1108/bij-04-2017-0077.

Ahmed, E. R., Islam, M. A., and \&amp;alabdullah, T. T. Y. (2018d). The moderating role of Shariah supervisory board on sukuk pricing benchmark. International Journal of Excellence in Islamic Banking and Finance 6.

Ahmed, E. R., Islam, M. A., and Harthy, F. N. (2013). The relationship between shareholders and Shubuhat: a study on the Islamic banks in Malaysia. Journal of Asian Scientific Research 3, 538-538.

Ahmed, E. R., Yahaya, S., and \&amp;harashid, M. (2012). Shubuhat on Matter of Bai'alinah and Tawarruq. International Journal of Business and Technopreneurship 2, 85-101.

Alabdullah, T. T. Y. (2016a). Agency Cost and Management Behavior: The Role of Performance as a Moderator. International Journal of Science and Research (IJSR) $5,1858-1864$.

Alabdullah, T. T. Y. (2016b). Agency Theory Perspective: A Quantitative Study Of Accounting Performance Measures In Emerging Economies. In ICTE Proceedings.

Alabdullah, T. T. Y. (2016c). Are Board Size And Ownership Structure Beneficial In Emerging Markets' Firms? Evidence From Jordan. International Journal of Management \& Information Systems (IJMIS) 20, 87-94. doi: 10.19030/ijmis.v20i3. 9752 . 
Alabdullah, T. T. Y. (2016d). Corporate governance from the perspective of the past and the present and the need to fill an international GAP. Risk Governance and Control: Financial Markets and Institutions 6, 96-101. doi: 10.22495/ rcgv6i4art12.

Alabdullah, T. T. Y. (2016e). The performance of companies and the board's characteristics from the new perspective of manipulation avoidance. Corporate Ownership and Control 13, 279-286. doi: 10.22495/cocv13i4c2p1.

Alabdullah, T. T. Y. (2017). Compensation committee, company board attributes, and company performance: The moderating effect of leadership position. Wei International Academic Conference Proceedings.

Alabdullah, T. T. Y. (2018). The relationship between ownership structure and firm financial performance. Benchmarking: An International Journal 25, 319-333. doi: 10.1108/bij-04-2016-0051.

Alabdullah, T. T. Y. and Ahmed, E. R. (2018). Corporate Governance: To What Extent it is important in the Arab Countries? International Journal of Science and Research 7.

Alabdullah, T. T. Y., Ahmed, E. R., and Nor, M. I. (2020). The World Declining Economy And Coronavirus Pandemic: Systems Should Be Continued. Russian Journal of Agricultural and Socio-Economic Sciences 102, 89-96. doi: 10.18551/rjoas.2020-06.11.

Alabdullah, T. T. Y., Alfadhl, M. M. A., .Yahya, S., and Rabi, A. M. A. (2014a). The Role of Forensic Accounting in Reducing Financial Corruption: A Study in Iraq. International Journal of Business and Management 9.

Alabdullah, T. T. Y., Nor, M. I., Ahmed, and R, E. (2018). The Determination of Firm Performance in Emerging Nations: Do Board Size and Firm Size Matter. Management 5, 57-66.

Alabdullah, T. T. Y., Yahya, S., Nor, M. I., and Majeed, F. Q. (2016). An Investigation of Corporate Governance From a New Perspective: Examining The Financial Performance of Companies and The Impact of Executive Turnover. Corporate Board: Role, Duties \&Composition 12, 53-67.

Alabdullah, T. T. Y., Yahya, S., and Ramayah, T. (2014b). Corporate Governance Mechanisms and Jordanian Companies' Financial Performance. Asian Social Science 10, 247-247. doi: 10.5539/ass.v10n22p247.

Alabdullah, T. Y., Sofriyahya, and Thurasamy, R. (2014c). Corporate Governance Development: New or Old Concept? European Journal of Business and Management 6.

Alfadhl, M. M. A. F. and Alabdullah, T. T. Y. (2013). Determinants of the Managerial Behavior of Agency Cost and Its Influential Extent on Performance: A Study in Iraq. International Journal of Humanities and Social Science, 3-3.

Ali, A. and Zarowin, P. (1992). The Role of Earnings Levels in Annual EarningsReturns Studies. Journal of Accounting Research 30, 286-286. doi: 10.2307/ 2491128.

Ali, W., Frynas, J. G., and Mahmood, Z. (2017). Determinants of Corporate Social Responsibility (CSR) Disclosure in Developed and Developing Countries: A Literature Review. Corporate Social Responsibility and Environmental Management 24, 273-294. doi: 10.1002/csr.1410.

and, T. A. (2019). Management Accounting and Service Companies' Performance: Research in Emerging Economies. Australasian Accounting, Business and
Finance Journal 13, 100-118. doi: 10.14453/aabfj.v13i4.8.

Baliga, B. R., Moyer, R. C., and Rao, R. S. (1996). CEO Duality and Firm Performance: What's The Fuss? Strategic Management Journal 17, 41-53.

Brooks, C. (2014). Introductory econometrics for finance (New York: Cambridge university press).

DiPeitro, W. R. and Anoruo, E. (2012). Government size, public debt and real economic growth: a panel analysis. Journal of Economic Studies 39, 410-419. doi: $10.1108 / 01443581211255620$.

Fauzi, F. and Locke, S. (2012). Board structure, ownership structure and firm performance: A study of New Zealand listed-firms.

Hashim, F., Ahmed, E. R., and Huey, Y. M. (2019a). Board Diversity and Earning Quality: Examining the Role of Internal Audit as a Moderator. Australasian Accounting, Business and Finance Journal 13, 73-91.

Hashim, F., Ries, E. A., and Huai, N. T. (2019b). Corporate Social Responsibility and Financial Performance: The Case of ASEAN Telecommunications Companies. KnE Social Sciences, 892-913. doi: 10.18502/kss.v3i22.5095.

Jensen, M. C. and Meckling, W. H. (1976). Theory of the firm: Managerial behavior, agency costs and ownership structure. Journal of Financial Economics 3, 305-360.

Omar, N. S. (2019). Innovation and economic performance in MENA region. Review of Economics and Political Science 4, 158-175.

Pfeffer, J. (1972). Size and Composition of Corporate Boards of Directors: The Organization and its Environment. doi: 10.2307/2393956. https://dx.doi.org/10.2307/ 2393956.

Rahim, A., Ahmed, N. F., Sarkawi, E. R., Jaafar, M. N., \&amp;shamsuddin, A. R., and $\mathrm{J}$ (2019). Operational risk management and customer complaints: the role of product complexity as a moderator. Benchmarking: An International Journal 26, 2486-2513.

Thottoli, M. M., Thomas, K. V., and Ahmed, E. R. (2019). Qualitative Analysis on Information Communication Technology and Auditing Practices of Accounting Professionals. Journal of Information and Computational Science 9.

Yermack, D. (1996). Higher market valuation of companies with a small board of directors. Journal of Financial Economics 40, 185-211. doi: 10.1016/0304405x(95)00844-5.

Conflict of Interest Statement: The authors declare that the research was conducted in the absence of any commercial or financial relationships that could be construed as a potential conflict of interest.

Copyright (c) 2020 Alabdullah, Ahmed and Abushammala. This is an open-access article distributed under the terms of the Creative Commons Attribution License (CC BY). The use, distribution or reproduction in other forums is permitted, provided the original author(s) and the copyright owner(s) are credited and that the original publication in this journal is cited, in accordance with accepted academic practice. No use, distribution or reproduction is permitted which does not comply with these terms. 


\section{LIST OF TABLES}

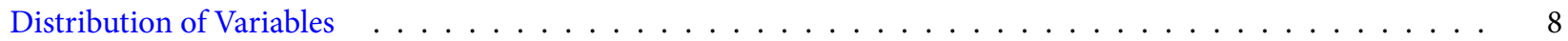

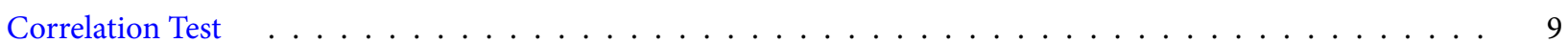

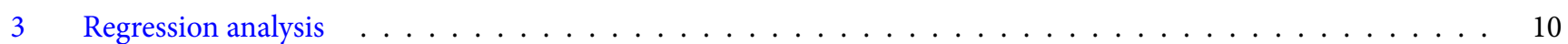


TABLE 1 | Distribution of Variables

\begin{tabular}{lllllll}
\hline Variables & Mean & Std.D & Min & Max & Skewness & Kurtosis \\
MR & .479 & .286 & .080 & .940 & .325 &.-1.282 \\
BSIZE & 8.89 & 3.359 & 3 & 15 & -.105 & -.105 \\
CDUAL & .32 & .471 & 0 & 1 & .775 & -1.445 \\
FS & 7.119 & .936 & 4.08 & 8.96 & $-.835-$ & .1 .021 \\
\hline
\end{tabular}


TABLE 2 | Correlation Test

$+)$
BSIZE
CDUAL
BSIZE
1
$0.718^{\star \star}$
CDUAL
$0.718^{\star \star}$
1


TABLE 3 | Regression analysis

\begin{tabular}{|c|c|c|c|}
\hline & \multicolumn{3}{|c|}{$\begin{array}{l}\text { Companies } \\
\text { Growth }\end{array}$} \\
\hline & \multicolumn{3}{|c|}{$\begin{array}{l}\text { Standardized } \\
\text { Coeff. }\end{array}$} \\
\hline Variables & Beta & t value Sig. & \\
\hline SBSIZE & $.396^{\star \star \star}$ & 2.502 & .015 \\
\hline CDUAL & -.127 & $-.804-$ & .424 \\
\hline FM & $-.232^{\star \star \star}$ & -2.115 & .039 \\
\hline
\end{tabular}

